Article

\title{
Rhizomatic Religion and Material Destruction in Kham Tibet: The Case of Yachen Gar
}

\author{
Daan F. Oostveen
}

Institute for Cultural Inquiry, Utrecht University, Achter de Dom 20, 3512 JP Utrecht, The Netherlands; dfoostveen@protonmail.com; Tel.: +31-622644706

Received: 1 August 2020; Accepted: 14 October 2020; Published: 19 October 2020

\begin{abstract}
This article looks at the Tibetan Buddhism revitalization in China in particular, in Kham Tibet, and the way how it was both made possible and obstructed by the Chinese state. As a case, we look at the Yachen Gar monastery in the West of Sichuan. The Yachen Gar monastery became the largest Buddhist university in China in the past decades, but recently, reports of the destruction of large parts of the Buddhist encampment have emerged. This article is based on my observations during my field trip in late 2018, just before this destruction took place. I will use my conceptual framework of rhizomatic religion, which I developed in an earlier article, to show how Yachen Gar, rather than the locus of a "world religion", is rather an expression of rhizomatic religion, which is native to the Tibetan highlands in Kham Tibet. This rhizomatic religion could emerge because Yachen is situated both on the edges of Tibet proper, and on the edges of Han Chinese culture, therefore occupying an interstitial space. As has been observed before, Yachen emerges as a process which is the result of the revival of Nyingmapa Tibetan Buddhist culture, as a negotiation between the Tibetan communities and the Chinese state.
\end{abstract}

Keywords: Yachen gar; Tibetan Buddhism; rhizomatic religion; Buddhist revival; Chinese religion; Nyingmapa

\section{Introduction}

During my field trip in November 2018 to the Yachen Gar ( Province of the People's Republic of China (PRC), it was one of the largest Buddhist monasteries in the world (Pedroletti 2017), benefiting from the expulsion of monks and the nuns from the regionally proximate Larung Gar monastery in Seda. In April 2019, Yachen Gar was sealed off for foreign visitors, following a similar ban in Seda earlier. Many of the nuns and monks living at Yachen were forced out. Now, reports and photos have emerged of the destruction of at least half of the West Bank encampment of Yachen Gar in August 2019 (Lewis 2019; Tenzin 2019).

Given the context of self-immolation of Tibetan Buddhists in China as a more violent form of resistance (McGranahan and Litzinger 2012; Woeser 2016), I propose to look at Yachen Gar as a less violent sublimation of the resistance of Tibetan women against attempts of control by the Chinese authorities in Kham Tibet. In this article, I will discuss the Yachen Gar Monastery from this perspective. What are the material expressions of violence in the conflict between state and Buddhism in the contemporary PRC? What happens in Yachen Gar? What can we learn about contemporary religion and state religion relations in China through Yachen Gar? What can the material conditions of Yachen Gar teach us about religion in China? I will argue in favor of the concept of rhizomatic religion (Oostveen 2019) to describe the religious belonging of the Yachen nuns, in the way how they both establish and subvert religious belonging to any set identitarian framework (Padma'tsho 2014). The belonging of the monks and nuns at Yachen is pragmatic, practical, and performative. 
In this article, first, I will give the context of the Tibetan Buddhism revitalization in China, as it has been thoroughly studied by Dan Smyer Yü (2012). I will connect this context to notes and memories from my field research trip to Yachen Gar, which I will not present as a genuine ethnography, but rather as an impressionist voyage. I am indebted to the analysis of Yasmin Cho (2020), who uses a Foucauldian-Whiteheadian theoretical framework to discuss the spatial politics of Yachen Gar and considers Yachen Gar as a "process", a standpoint I strongly agree with. My own analysis of the Tibetan Buddhism revitalization in general, and the role of Yachen Gar in this, in particular, centers around the concepts of the rhizome (Deleuze and Guattari 1987) and the nomadic (Braidotti 2011). I will argue that the material culture of Yachen Gar, the temporary "shacks" build by the nuns themselves, are a way to subvert the territorialization attempts of Tibetan culture by the Chinese state in a nomadic and non-violent way. While the Chinese government emphasizes building a modern state, the Tibetan nuns are able to subvert this precisely by emphasizing the temporality of their "encampment". Their culture is rhizomatic and fluid, and demolition attempts of the Chinese government, which are an attempt to discipline Tibetan Buddhism in function of the Chinese state, are subverted by a more ancient rhizomatic religion, which cannot be grasped definitively.

Since I am not able to talk to the nuns in their native language, my methodology is necessarily limited. I have chosen to study the material expression of Yachen Gar as it emerges in and of itself. Though this will no doubt hinder my possibility of a full hermeneutical self-understanding of the nuns of Yachen Gar, I do believe that it also enables me to take a more detached post-human approach to Yachen and its human and non-human inhabitants, which is valuable in and of itself.

\section{Tibetan Buddhism Revival in China}

Kham Tibet is a region in Western Sichuan province. Historically, it was the most Eastern of five regions of Tibet. It spans an area covering parts of the TAR, Sichuan, Gansu Province and Yunnan Province. Culturally, it is the center of the Nyingma school of Vajrayana Buddhism. The Kham region in Sichuan is generally easier to access for foreign visitors than the TAR. Yachen Gar is situated in the Baiyü county of the Garzê Tibetan autonomous prefecture. The administrative and moral capital of the Garzê Tibetan autonomous prefecture is Kangding, or Dartsedo (or Dardo) in Tibetan: The "Eastern Capital" of the Tibetan Empire. In Chinese culture, Kangding is famous for a universally recognized folk song: “Kang Ding Love Song 康定情歌”. Kangding serves now as a gateway to the Garzê prefecture on route from the proud Sichuan capital Chengdu. It is administratively mostly run by Han Chinese, many of whom have settled down in Kangding in the past decades.

As is often the case in the contemporary PRC, religious practitioners at Yachen Gar painstakingly try to avoid any political association. If prompted, their loyalty to Socialist China is expressed beyond any doubt. However, more significantly, among religious practitioners, there is the complete absence of political associations. About a fourth of the territory of the PRC can be designated as part of the Tibetan cultural sphere. This fact should not be underestimated: It shows the necessity for the Chinese government to territorialize their "New Tibet" firmly within China. The TAR is only a portion of this enormous space, though it is the most controlled. Since the vast Tibetan cultural borderlands of the TAR, in Sichuan province, in Qinghai province, are not under the same level of control as the TAR, Tibetan Buddhist communities are able to establish their practices in a less restricted way (Cho 2020). For the Chinese authorities, however, it is of prime importance to fit these vast Tibetan territories into the political framework of "China". The balance between minority cultures and the Chinese state is always a delicate one, especially in a country with a $92 \%$ Han majority.

The monastery of Yachen Gar has to be situated in the context of the Tibetan Buddhism revivalist movement. Over the past decades, the Tibetan culture and Buddhism in China has had the opportunity to thrive, at least under certain particular conditions. Tibetan Buddhism is divided into a few distinct schools: Most famous are the Geluk school (Gelukpa), which is most famous because of its spiritual leader the Dalai Lama and the Nyingma school (Nyingmapa), which is the oldest school of Tibetan Buddhism (about 300 years older than Gelukpa) (Dorje and Kapstein 2012). The Gulakpa is aimed 
more at a dovetailing of spirituality and politics. Moreover, it is more aimed at the preservation of emphasis on a Tibetan national culture. The revivalism of Gelukpa in China has therefore been more characterized by political activism against the Chinese state (Schwartz 1994) and a stronger association with the Tibetan government in exile in India. The response of the Chinese government has been one of strong oppression of any politicized form of Tibetan Buddhism. The Nyingmapa, on the other hand, does not emphasize any national political goal. Their aims are more soteriological and aimed at popularizing Tibetan Buddhism in the globalized world. Nyingmapa, for its sake of being less political, has therefore been less active in the heartland of Tibet around Lhasa and the TAR, but thrived more in the margins of cultural Tibet, such as Kham Tibet in Sichuan Province and Amdo in Qinghai Province. This placement at the margins and their soteriological emphasis has actually benefitted the Nyingmapa in recent decades. The Larung Gar and Yachen Gar monasteries have to be viewed in this light.

The relation between Tibetans and the Chinese state in this respect should not be regarded only as one of opposition, in which one side are the villains (the Chinese state) and the other the victims (the Tibetans). In fact, the Nyingmapa has been able to attract a large number of Han Chinese practitioners. Propelled by offering a very practical way towards redemption, its message spoke to many urbanites in the almost proverbial spiritual poverty of Chinese modernism. The impact of this spiritual message is the result of the combination of the charisma of the tulku's, which the Tibetans understand to be enlightened beings in a human body, who founded the monasteries of Larung Gar and Yachen Gar, and the emergence of what I call Techno Buddhism: The accelerated dissemination of the Buddhist message (the "Buddha dharma" 佛法) in the digital sphere through microblogging, WeChat, and viral videos on platforms such as Douban (which spinoff TikTok is currently causing great turbulence and controversy in the West).

For the Chinese state, there is an interest in binding Tibetan culture intimately to the Chinese national framework. Far from destroying Tibetan culture, the Chinese politics of Tibet is aimed at modernization of Tibetan culture within the country of China. To that end, Tibetan cultural expressions are actually supported, and infrastructural projects are undertaken and encouraged. But of course, this is a double-edged sword. The Chinese state has an interest in stimulating Tibetan culture in function of embedding it strongly within the political framework of Zhong Guo 中国. This Tibetan culture should be firmly embedded territorially in within China, a process that has been labeled "territorialization" (Yeh 2013).

\section{A Visit to Yachen Gar}

"Yachen" was historically the name given to the plain by nomadic people. Yachen Gar was founded in 1985 by Lama Achuk Rinpoche, who died in 2011, the official name being the Yaqên Orgyän Temple. Achuk Rinpoche was a Dzogchen practitioner of the Nyingmapa of Vajrayana ("Tibetan") Buddhism. After his death, he was succeeded in leadership by Asang Tulku. Dzogchen in the goal of "Great Perfection", as it is called in the West. This form of enlightenment can also be attained, in this Buddhist philosophy, by lay people, which partly explains its popularity. The soteriological direction of Nyingmapa makes its philosophy more palatable to the Chinese authorities than the inherent political orientations of the Gelukpa (though the opposite, namely that Nyingmapa are precisely targeted, and the Gelukpa left alone for the same reason, is sometimes also the case).

At the time of my visit, the monastery at Yachen Gar hosted, according to unofficial estimates, about 10,000 nuns and about 2000 monks. The nearby Larung Gar monastery had recently come under severe pressure from the Chinese government, including demolitions of the living quarters and evictions. Therefore, many nuns and monks had relocated to Yachen Gar (Wong 2016). At Yachen Gar, several large construction projects were under process, presumably to accommodate the expected influx of "refugees" from the even larger Buddhist monastery of Larung Gar in Seda, which originally hosted 40,000 practitioners. We arrived in Yachen at noon by taxi after a two-hour drive from the Garzê township. The encampment is situated at a wide Himalayan plane at an altitude of $4000 \mathrm{~m}$. On the day of our visit in November 2018, it was a cold, windless day under a crisp blue sky. We traveled with 
a group of four: A writer and artist from the Netherlands, a scholar and artist colleague from Russia, and a girl we met in our local hostel in the town of Garzê from Germany. On our arrival, we had to pass through a passport and security checkpoint. Together with the local post office, these were the most visible signs of PRC presence at the monastery. The term monastery might be misleading to a naïve observer. Yachen Gar is set up as an extended shantytown on two sides of a river, with hundreds of small self-made huts, typically sheltering one nun. Alternately, the terms "encampment" or "monastery" are being used to describe Yachen. The Tibetan word "Gar" has become a common reference to refer to this type of religious encampment in the Tibetan cultural region.

The encampment of Yachen Gar is divided by a river (Figure 1a). The road from which you arrive enters on the North side of the river. Here are the largest constructions situated, as well as the dwellings of the 2000 monks. The South side of the river is reserved for the nuns (Figure 1b), whose dwellings have proliferated over the past few decades, until the Chinese government decided to define the area more strikingly by constructing a ring road around the shantytown and establish a construction ban outside of this area (Cho 2020).

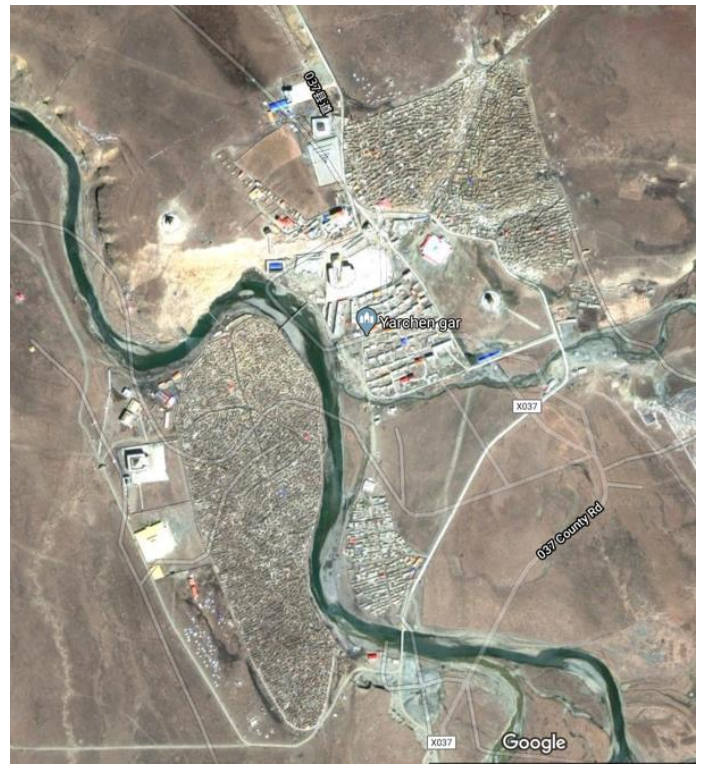

(a)

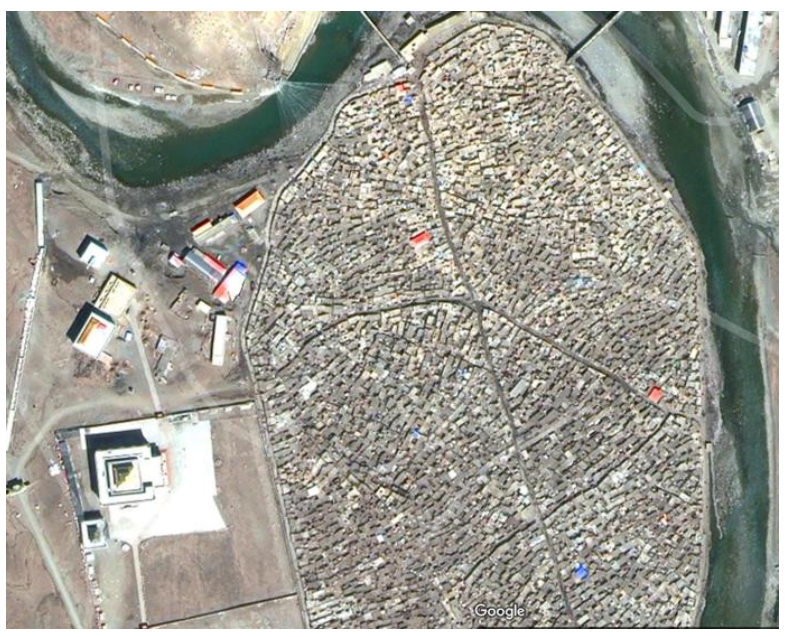

(b)

Figure 1. (a) The satellite photo of Yachen Gar clearly shows the spatial set-up. The main buildings, as well as the living quarters of the monks, are situated on the northern side of the river. (b) (detail) The nun's living quarters are on the south side. According to recent reports, the entire eastern part of the nun's living quarters on the embankment of the river was demolished. Source: Google Maps.

At the time of our visit, we could roam freely around the encampments. On the south side of the riverbank, we could walk on the main roads, though we were kindly requested by the nuns not to deviate into the living quarters. Yachen Gar has barely any restaurants and only a few convenience stores. Its economy is self-organizing. Communication appears to be based on the highly popular WeChat app, and most of the nuns carried phones and headphones.

At around 2 pm, we entered a temple building, which also served as a dinner hall for the monks, on the north side of the river. Even a Han Chinese tourist was a rare sight in Yachen, let alone four white tourists. Unlike other remote places in China, though, where whiteness always attracts much interest, in Yachen it almost appears as if we were invisible. No noticeable attention was given to us. We sat for about ten minutes at the back of the dinner hall before a monk noticed us and made eye contact. The food distributors were then summoned to pass by us and offer us food as well. We also witnessed the chanting rituals of the nuns in one large public building (Figure 2 and Supplementary Materials). 


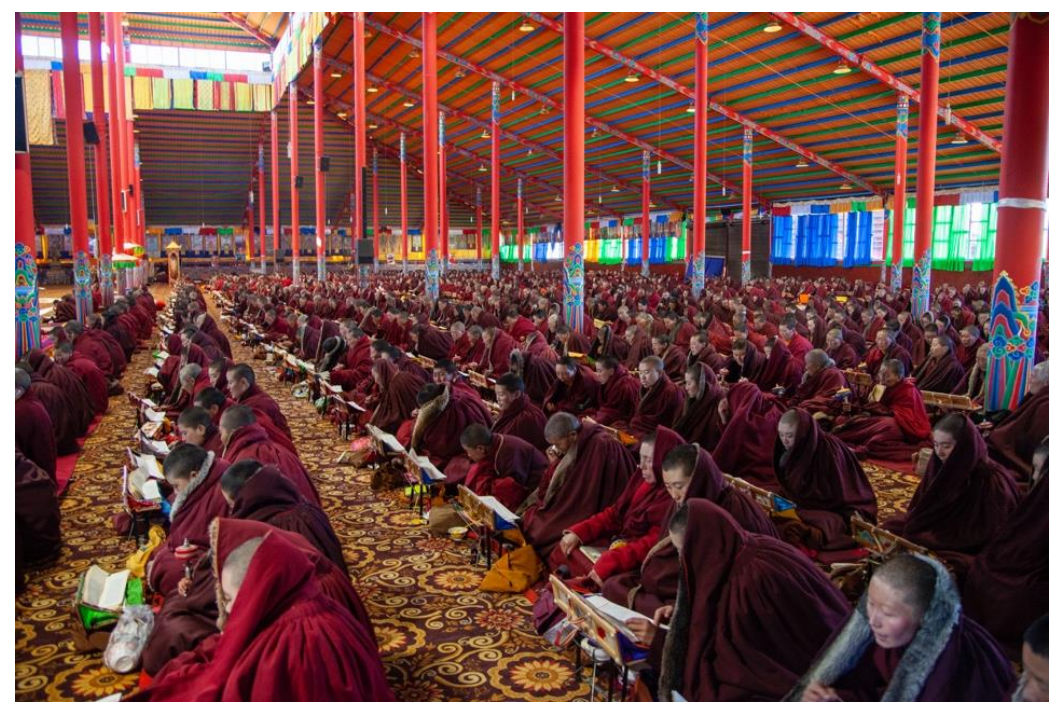

Figure 2. Behind the large encampment, several public buildings served for the ritual practices of the nuns. In one of them, we encountered hundreds of nuns chanting sutras.

I might need to reflect on my own position at this point. I am not trained as an anthropologist, but as a philosopher and as a theoretician of trans-religiosity and Asian religion. I am aware that my presence as a "white scholar" in an area described by its "remoteness" is problematic. Furthermore, I do not have the linguistic skills to have had conversations in Tibetan at Yachen. In that sense, I arrived as a naïve observer. Much attention has been devoted to the problematic nature of the Western observer of the exotic "other" in anthropology and there is no need here to repeat those arguments. In the academic and artistic milieus of Beijing, it has recently been equally fashionable to engage in projects which take Minzu or minority people as their object of study. Therefore, Han intellectuals are at risk of repeating the mistakes of their Western counterparts. In conclusion of this short excursus: my position as a white male European intellectual-majoritarian in the double sense of being neither Chinese nor Tibetan-necessarily leads to a sense of objectification and estrangement that is inherently problematic. It is, however, the only thing I have at my disposal.

A striking feature of Yachen Gar is the small meditation cells scattered around the hill next to the river and also scattered around a field West of the nunnery encampments (Figures 3 and 4). The practice of long solitary meditation is a primary feature of the prescribed practice of the nuns at Yachen, in aspiration of the Great Perfection or Dzogchen. These huts were makeshift constructions, each differently built. The entrance was sometimes not more than a small prefab window, which allowed only a small person to enter. The huts were barely over a meter high and could only fit one small person sitting for meditation. Some huts were equipped with blankets and liturgic books.

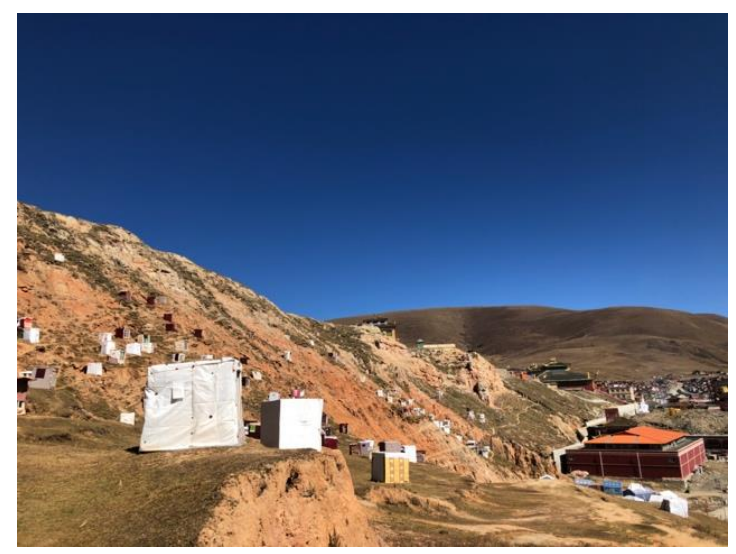

Figure 3. Meditation huts on the hills. 


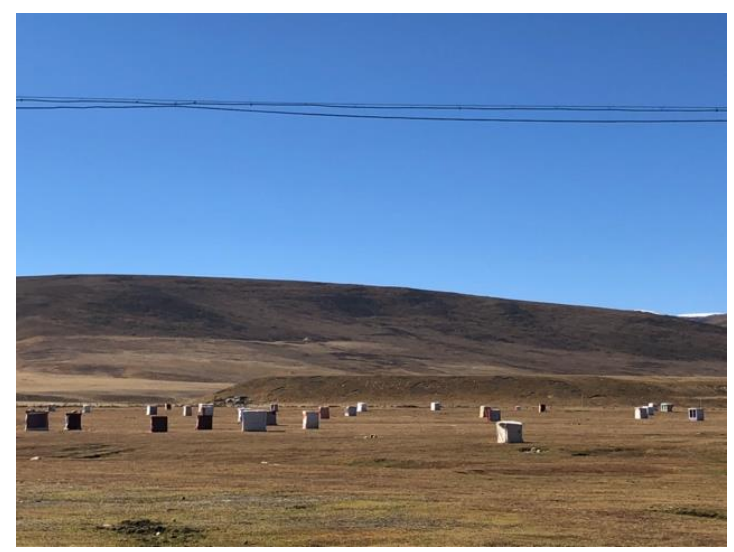

Figure 4. Meditation huts scattered around the field just outside the main quarters.

On leaving Yachen, I met a Han Chinese group of people who came from Wuhan. The man supposedly worked at Wuhan University, something which I have not been able to confirm. They were the only other tourists we were able to identify on our visit. The man and women confirmed the story of Chinese development in the Tibetan regions. Upon our testimony that Larung Gar had remained closed to us, they reacted in surprise. They were not aware of any travel restrictions. They did, however, emphasize that the hygienic conditions in Larung Gar were inferior to Yachen Gar. This group clearly belonged to a more adventurous interest among Han Chinese.

\section{Rhizomatic belonging in Kham Tibet}

The religious policy of the PRC is guided by a model of religious diversity inherited from the early Republican period, in which the conceptual model of Three Teachings (sanjiao 三教: Daoism, Confucianism, and Buddhism) was, as a result of modernization movements, replaced by a model of five "religions" (zongjiao 宗教, literally "sectarian teachings": Catholicism, Protestantism, Islam, Daoism, and Buddhism). Within this framework, religious activity in China is "legal", as long as religious groupings report themselves to the local office of the bureau for religious affairs (SARA).

The idea of "rhizomatic religion" is an application of Deleuze and Guattari's theory of the rhizome onto religious diversity. Critical theory has often been skeptical of dealing explicitly with religion, understanding at usually as a backward form of knowledge. The idea of the rhizome proposes an alternative to "arborescent" thinking. Commonly, diversity is understood as having a root structure with a unified origin, from which various "branches" are derived. Deleuze and Guattari propose to understand diversity not as a "tracing" of various branches, but rather as a "map" of interconnected diversity.

Rhizomatic religion means understanding religion as an interconnected structure of a myriad of religious forms, smells, sensations, ideas, words, sounds, etc. which enables improvisation, play, and belonging for its participants. In religious studies, the concept of the rhizome entails a double rejection. The first is the rejection of the world religions paradigm, the idea that "religions" are various instantiations in the form of faith systems of the category "religion": Christianity, Islam, Buddhism, etc. The second is the rejection of the idea of religious pluralism, which states that all religions are equally valid and are derived from a universal "core", the "essence" of religion, e.g., the idea that all religions teach the Golden Rule of ethics, or that all religions are about love, or that religion is something that all human beings have in common (Oostveen 2018). Rhizomatic religion offers an alternative to understanding religion. It is an answer to the question "why still religion?" (Vries 2008). In the context of China, rhizomatic religion rejects the model of religious diversity of SARA and the PRC, which serves as a way to "divide and control" the religious practices of the people, especially the minorities, or use religious traditions in function of strengthening the Chinese nation (Chinese Buddhism and Daoism, in particular). 
The encampment of Yachen can be seen as a process (Cho 2020): Its material conditions are in continuous flux and transformation. For the nuns at Yachen, the space offers a unique opportunity to live a monastic life and live close to the most influential tulkus of this time. Since monks generally have a higher standard in Tibetan Buddhism, the opportunities for women to become nuns are even rarer. These women sometimes come from hundreds of kilometers away, from Lhasa or more central Tibetan areas. They have carved out a unique sense of belonging in this temporal space. It is the rhizomatic belonging that is always delayed, always in the process of becoming, and always at risk of being shaken up again. The unique architecture and material living conditions of the nuns is a striking expression of this transformative way of being.

The Yachen Gar monastery has a nomadic character (Braidotti 2011). The designation "encampment" shows the perceived temporality of the school, as if the nuns and monks are only for the time being making camp at the feet of the master. It also echoes the Buddhist conviction that everything is impermanent. It is precisely because of this nomadic character that it has the potential to thrive, as the only way to subvert the Chinese campaign to transform Tibet in line with Chinese modernization, and to fit this New Tibet into the framework of Chinese nationalism (Smyer Yü 2012). This dynamic, interconnected form of homemaking in religion is characteristic for what I have identified as rhizomatic religion. Of course, current destructions of the dwelling grounds signal an attempt by the authorities to control a form of spatial politics on the encampment. In some cases, prefabricated houses were supplied by the Chinese government in negotiation with the monastic authorities to structure the living conditions of the nuns in a way more to the liking of the Chinese authority. Similarly, the ring-road around the encampment already can be seen as a signal of the attempt to curtail the weeding out of the encampment. The nuns themselves, however, appear to be in a state of permanent nomadism - even "leaving home" (出家) at the monastery itself to retreat into the even smaller mediation huts shattered around the hills around the encampment (see Figures 3 and 4). Some have built meditation huts on their already tiny houses (Figure 5).

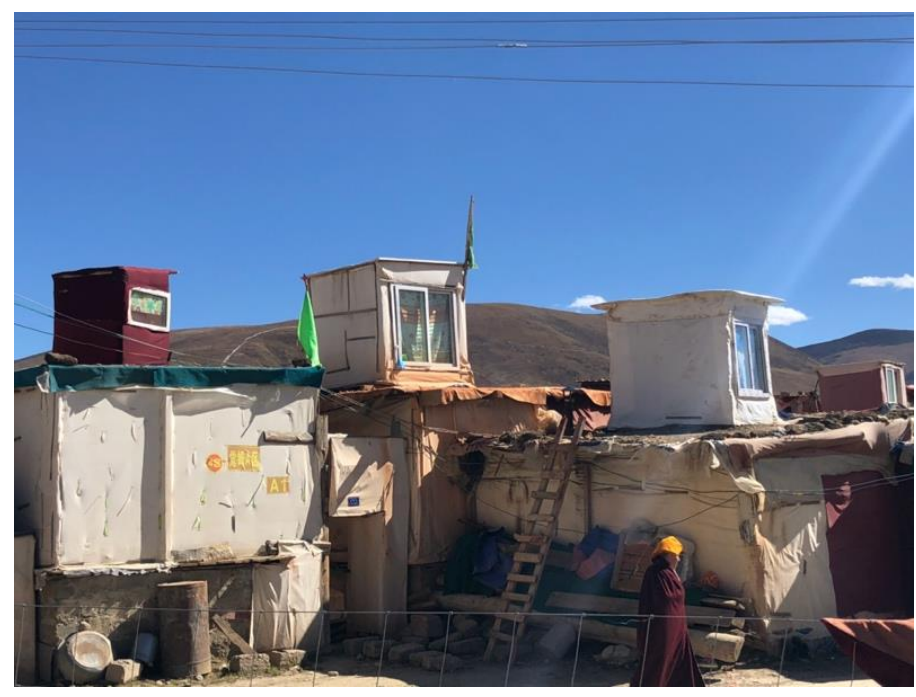

Figure 5. Makeshift houses at Yachen Gar with meditation huts on top of them.

The nuns at Yachen Gar have turned their precarious conditions into an opportunity, guided by the repressing features within their own culture-in which women are often seen as metaphysically inferior to men - and by repression of their culture by the Chinese state. It is maybe even caused by this double repression that the nuns of Yachen have found this particular line of flight (Deleuze and Guattari 1987). 


\section{Conclusions}

Religion in China cannot be detached from the ever present and intervening Chinese state. Religion in Tibet presents itself almost necessarily as a "problem" at best, and as a violent confrontation at worst. In the case of the Gelukpa in the TAR, this has led to cultural repression and control from the side of the Chinese government, and resistance in the form of self-immolations. The Tibetan Buddhism revitalization of the Nyingmapa in Kham and Amdo emerges as an alternative story to the polarized narrative about the place of the Tibetans in the Chinese state: An expression of the inherent rhizomatic character of religion. More aimed at soteriology and teachings, as well as reaching out to Han Chinese, urbanites and with an agenda towards globalization, using the tools of Techno Buddhism, the Nyingmapa tulku's and their followers, both lay and monastic, have been able to carve out a third space between Tibet proper and Han-dominated China. With Larung Gar as the first example of this interstitial and rhizomatic religion, Yachen Gar has emerged as the central alternative node of the Tibetan Buddhist revivalism in China following the increased exertion of control in Larung Gar over the past decade.

The material religious culture of Yachen Gar is nomadic, rhizomatic, and subversive of both the patriarchal Tibetan Buddhism, as well as the control and repression of Tibetan culture by the Chinese state. Yarchen Gar is carved out by the inventiveness of the Tibetan women who found a temporary space in which they can thrive in between the dominant Tibetan culture and the attempt of territorialization of Han dominated China. The recent bouts of destruction still need to be thoroughly evaluated. As is often the case with Chinese politics, these demolitions should be seen as a move in a long game of chess. Chinese policymakers know that the Nyingmapa can be played towards the interests of Socialist China, precisely because the Nyingmapa have sublimated the more explicitly violent anger, which is more prominent in Gelukpa Tibetan Buddhism. The nuns of Yachen Gar build their makeshift dwellings, supported by the authority of Yachen Gar. The Chinese authorities respond by partial demolitions, just enough to raise the nerves and show who is the boss. It is these material politics in this interstitial space between Han China and Tibet that show how Yachen Gar is the most current locus of confrontation between two Asian cultural powers.

Supplementary Materials: The following are available online at http://www.mdpi.com/2077-1444/11/10/533/s1, Audio recording 1: nuns chanting sutras in Yachen Gar, November 2018.

Funding: This research received no external funding.

Conflicts of Interest: The author declares no conflict of interest.

\section{References}

Braidotti, Rosi. 2011. Nomadic Theory: The Portable Rosi Braidotti. New York: Columbia University Press.

Cho, Yasmin. 2020. Yachen as Process. Encampments, Nuns, and Spatial Politics in Post-Mao Kham. Frontier Tibet. In Patterns of Change in the Sino-Tibetan Borderlands. Edited by Stéphane Gros. Amsterdam: Amsterdam University Press.

Deleuze, Gilles, and Félix Guattari. 1987. A Thousand Plateaus: Capitalism and Schizophrenia. Minneapolis: University of Minnesota Press.

Dorje, Gyurme, and Matthew Kapstein. 2012. The Nyingma School of Tibetan Buddhism: Its Fundamentals and History. Somerville: Wisdom Publications.

Lewis, Craig. 2019. New Images Reveal Extent of Demolitions at Yarchen Gar Buddhist Monastery. BuddhistDoor, September 6. Available online: https://www.buddhistdoor.net/news/new-images-revealextent-of-demolitions-at-yarchen-gar-buddhist-monastery (accessed on 18 October 2020).

McGranahan, Carole, and Ralph Litzinger. 2012. 'Self-Immolation as Protest in Tibet'. Hot Spots, Fieldsights. April 9. Available online: https://culanth.org/fieldsights/series/self-immolation-as-protest-in-tibet (accessed on 18 October 2020).

Oostveen, Daan F. 2018. Multiple Religious Belonging and the ‘Deconstruction' of Religion. Exchange 47: $39-52$. [CrossRef] 
Oostveen, Daan F. 2019. Religious Belonging in the East Asian Context: An Exploration of Rhizomatic Belonging. Religions 10: 182. [CrossRef]

Padma'tsho. 2014. Courage as Eminence: Tibetan Nuns at Yarchen Monastery in Kham. In Eminent Buddhist Women. Edited by Karma Lekshe Tsomo. Albany: State University of New York Press, pp. 185-94.

Pedroletti, Brice. 2017. Les moines tibétains de Yarchen Gar sous l'œil de Pékin. Paris, France: Le Monde, March 30.

Schwartz, Ronald David. 1994. Circle of Protest: Political Ritual in the Tibetan Uprising. London: Hurtz \& Company.

Smyer Yü, Dan. 2012. The Spread of Tibetan Buddhism in China: Charisma, Money, Enlightenment. Abingdon and New York: Routledge.

Tenzin, Kunsang. 2019. Photo Shows Dramatic Demolition of Yachen Gar Buddhist Complex. Radio Free Asia. Available online: https://www.rfa.org/english/news/tibet/sichuan-yachengar-08282019173854.html (accessed on 18 October 2020).

Vries, Hent de, ed. 2008. Religion: Beyond a Concept (The Future of the Religious Past). New York: Fordham University Press.

Woeser, Tsering. 2016. Tibet on Fire: Self-Immolations against Chinese Rule. London and New York: Verso.

Wong, Edward. 2016. In Remote Settlement High on Tibetan Plateau, Buddhist Spirituality Soars. New York: The New York Times.

Yeh, Emily T. 2013. Taming Tibet: Landscape Transformation and the Gift of Chinese Development. Ithaka and London: Cornell University Press.

Publisher's Note: MDPI stays neutral with regard to jurisdictional claims in published maps and institutional affiliations.

(C) 2020 by the author. Licensee MDPI, Basel, Switzerland. This article is an open access article distributed under the terms and conditions of the Creative Commons Attribution (CC BY) license (http://creativecommons.org/licenses/by/4.0/). 